\title{
Subsurface flexure of Uemachi Fault and its characteristics in Osaka plain
}

\author{
Naoko Kitada ${ }^{\text {i) }}$ and Mamoru Mimura ${ }^{\text {ii }}$
}

i) Chief Researcher, Geo-Research Institute, 4-3-2 Itachibori, Nishi-ku, Osaka City 550-0012, Japan.

ii) Professor, Department of Urban Management, Kyoto University, Kyoto daigaku-Katsura, Nishikyo-ku, Kyoto 615-8530, Japan.

\begin{abstract}
In Osaka, Uemachi Fault is one of the famous active faults. It across the center of Osaka and lies in N-S direction mainly and is more than $40 \mathrm{~km}$ in length. These sediment are very thick layers over $1000 \mathrm{~m}$ therefore, fault structure are appeared as flexure zone (only vending the strata) and hidden the fault displacement around the surface. Main Uemachi fault trace are distributed near Uemachi uphill and two spray fault (Suminoe and Sakuragawa) is distributed NE-SW. The Headquarters for Earthquake Research Promotion have reported the average displacement rate of main Uemachi fault is about $0.4 \mathrm{~m} / \mathrm{ka}$ (ka is kiro age before). However, because of modified by erosion and urban development, main fault (N-S direction) is difficult to estimate the displacement rate near the surface. In this study, we try to estimate the width of flexure zone using geotechnical borehole data. These spray faults does not make clear the distribution and also these length. Upper Pleistocene marine clay (Ma12) is a good indicator of the flexure zone. Ma12 marine clay layer is correlated to marine isotope stage 5e, therefore the marine clay bottom age is considered about 125ka. We constructed many cross sections in and around the fault zone and found that Ma12 marine clay layers were folded and were recognized on both the up and down sides of the flexure. The result of this study, the displacement rate of the flexure zone is $0.26 \mathrm{~m} / \mathrm{ka}$ and distributed parallel to the main fault. It about $12 \mathrm{~km}$ length and the Sakuragawa and Suminoe flexure are continuing and seemed to be the one of the main fault in the Uemachi fault system.
\end{abstract}

Keywords: faults, marine clay, geology, earthquake

\section{INTRODUCTION}

The Uemachi Fault in Osaka is one of the important active faults that control tectonics and sedimentation in Osaka Basin. The sediments in Osaka Basin are over $1000 \mathrm{~m}$ thick and start to subsidence of the basin and aggradation from 3.5 million year before (Kitada et al., 2011). Cyclic climate change has occurred since 1.3 million year before and marine clay layers have deposited in the central Osaka during warm and high sea water period. Marine clay layer have been deposited at least 15 layers including Holocene soft marine clay. The stratigraphy of this sedimentary sequence, known as the Osaka Group, has been summarized for upland areas on the basis of correlation of marine clay beds and volcanic ash layers.

The Uemachi fault is more than $40 \mathrm{~km}$ in length and two spray fault called Sakuragawa and Suminoe flexure are distributed NE-SW (Fig.1). The deformation can observed using seismic profile. Vertical deformation is at least $600 \mathrm{~m}$ on the top of the basement rock. Many seismic profiles realized the distribution of the fault, however, the amount of displacement decreases toward the surface and seem to be partially observed by flexure (Fig.2). Therefore, the surface rupture is not clear. These flexure zone need attention of amplified the seismic wave not only the fault displacement. From 2010, Project of focus investigations for Uemachi fault has been started and makes clear the distribution of this flexure zone using borehole database. In this project, we try to consider the distribution of these flexure using borehole and Ma12 marine clay layers as the key layer.

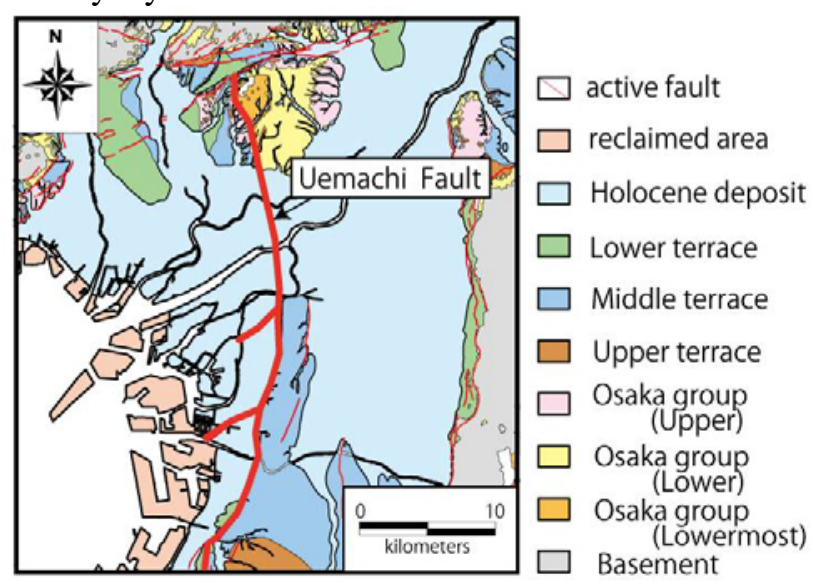

Fig. 1. Geological and tectonic map of area around Osaka Area (Active fault map in urban area, 1996) 


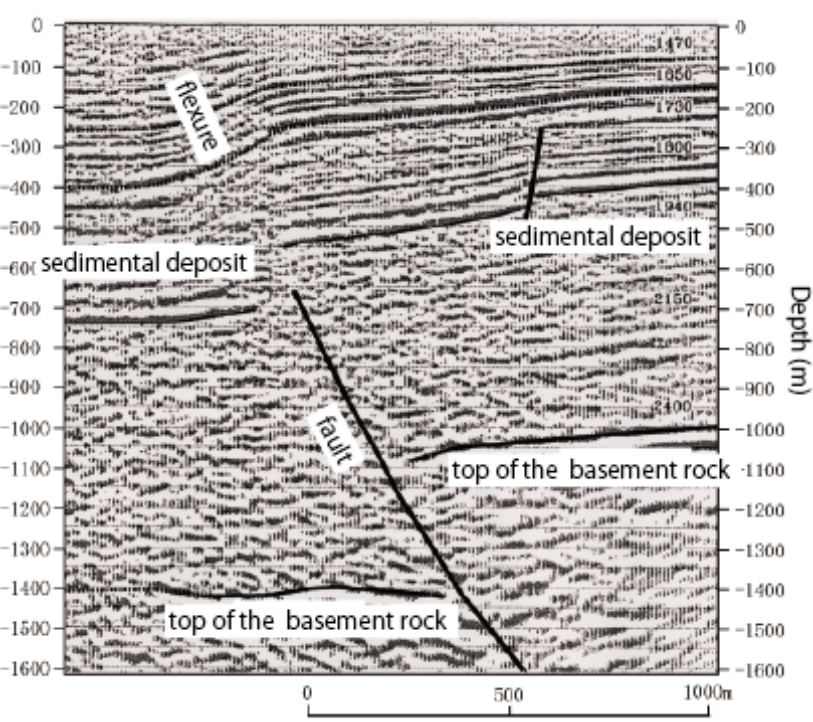

Fig. 2. Seismic profile shows the fault in the basement rock changed flexure toward the near surface. (Osaka city, 1996)

\section{SUBSURFACE STRUCTURE ALONG THE UEMACHI FAULT}

\subsection{Borehole database}

In the Osaka basin, about 60,000 borehole data was collected and in the Uemachi fault zone, about 2000 borehole data can used to study about subsurface structure. Geological subsurface structure in the Osaka basin is considered about delta deposit area (lowland) and sometimes in the marine environment due to the sea level change. Marine clay layers were formed in the marine environment; therefore these layers were deposited under the horizontally-bedded layers.

Fig. 3 shows the E-W cross sections of the Osaka basin. Blue and green strata show the marine clay layers. The west lowland area showing the horizontally flat layered marine clay layers can observe in the Osaka plain. However, Uemachi uphill were formed by the structural movement of Uemachi fault and marine clay layers were deformed caused by the movement of Uemachi fault.

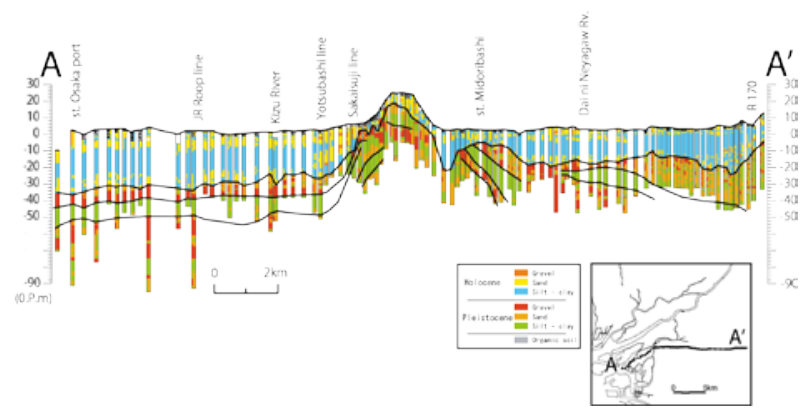

Fig. 3. Geological cross section across the Osaka plain (Geo-database Information Committee of Kansai, 2007)

\subsection{Subsurface structure around Uemachi fault}

We first examined the borehole data along the seismic reflection line and then considered the surrounding area. An example of this analysis is shown in Fig. 4, which highlights the fact that the buckling is expressed particularly well in the marine clay layers. Upper Pleistocene marine clay (Ma12) is a good indicator of the flexure zone. We constructed many cross sections in and around the fault zone and classified the deformation form into three categories around the flexure zone. Partially, main fault area (N-S direction) is not distributed of marine clay layers; therefore, these areas can consider the marine clay continuity but not identify the number of marine clay.

Many cross sections can be classified into three types: (1) Ma12 folding, (2) Ma12 folding that does not continue toward the hanging wall, and (3) folding or displacement of old marine clay.

Type (1) appears the perfect configuration of flexure zone. Ma 12 clay is folding and continues toward the hanging wall. The vertical displacement is about $40 \mathrm{~m}$. Type (2) showed the folding shape, but the hanging-wall side appears to be denuded. Type (3) showed the displacement or folding shape near the fault, however, marine clay number has not been determined. These marine clay layers seem to be old marine clay. Type 3 is mainly distributed around Uemachi in upland areas. Fig. 5 shows these three types of the fault zone.

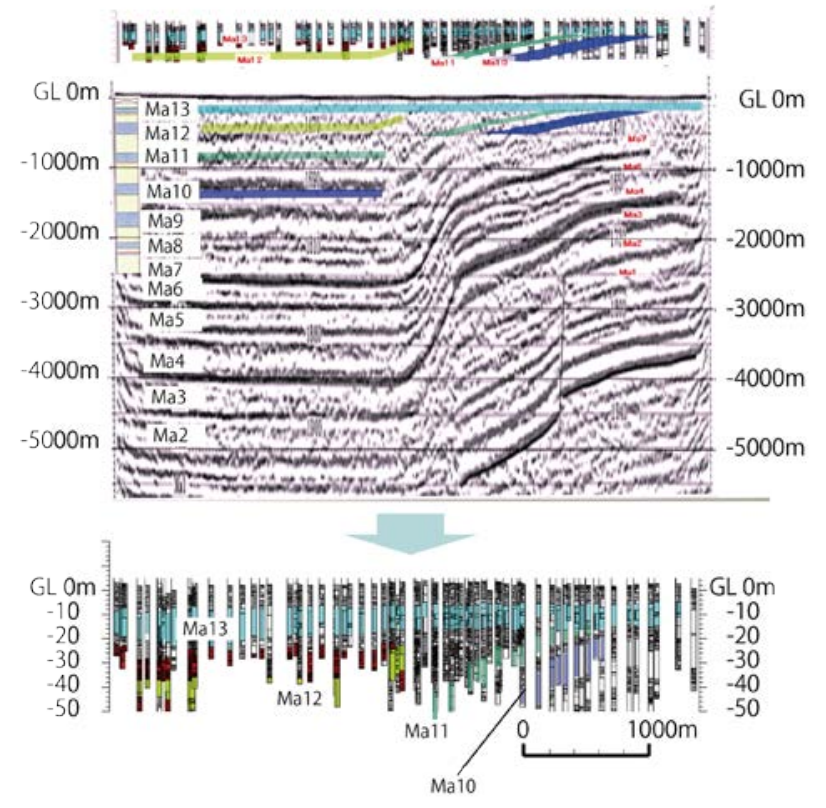

Fig. 4. An example of extraction of the subsurface flexure zone compared with seismic profile and borehole data. Marine clay layer Ma12 were bending near the flexure and Ma13 (Holocene) covered these layer. (Seismic profile: Osaka city, 1996) 


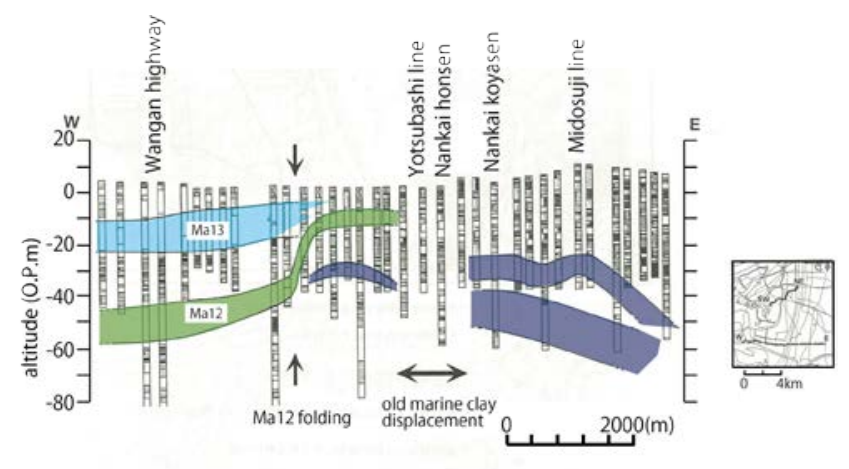

(a) Type(1)

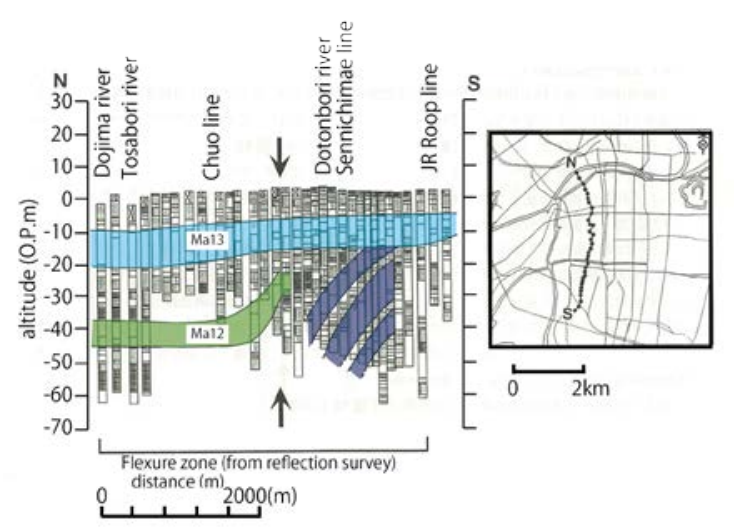

(b)Type(2)

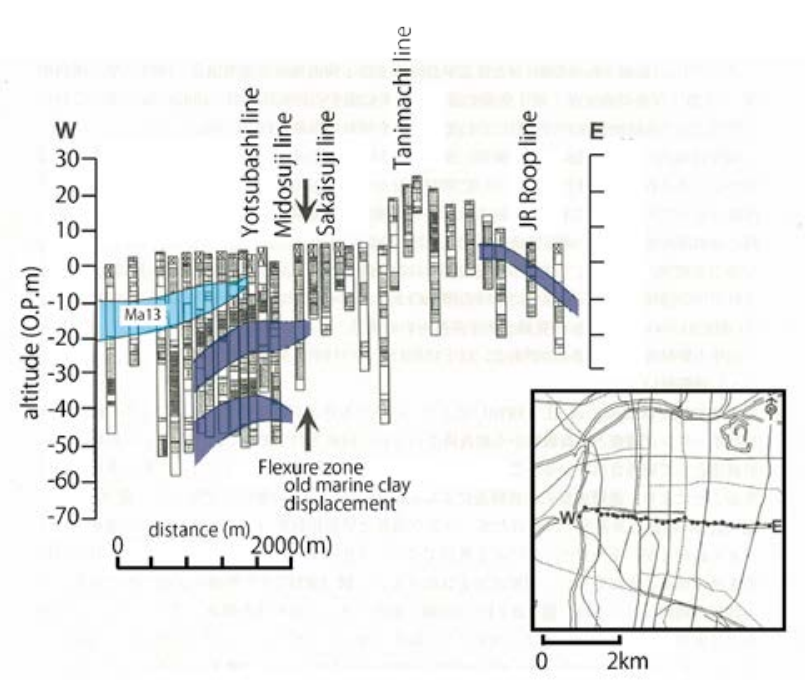

(c) Type (3)

Fig. 5. Subsurface structure of Uemachi fault using borehole database. There are three patterns observed. (a) Ma12 is certainly deformed plastically. (b) Ma12 seems to be deformed however folding does not continue toward the hanging wall. (c) Old marine clay layers are folding or bending near the Uemachi fault.

\section{RESULTS AND DISCUSSION}

In the Osaka plain, many borehole sections have made and considered the distribution of folding of three types. Fig. 6 shows the result of distribution of Uemachi fault. In this figure, red line is type (a) and orange line is type (b). These two lines are distributed more western side of Uemachi uphill in the plain. The Blue line is type (c). This fault trace (c) conform to the Uemachi uphill, but (a) and (b) are step away to the western in the lowland.

In order to estimate the displacement along this fault, geological drilling was carried out as a part of a project studying the Uemachi active fault system in FY2011 by Ministry of Education, Culture, Sports, Science and Technology. A core sample (UMH22-1) was obtained in the Sakuragawa flexure zone; this borehole was 120 $\mathrm{m}$ deep and core samples were analyzed using tephrochronological methods, and Ma5, Ma6, Ma8, Ma12, and Ma13 marine clay layers have been correlated with data from surrounding boreholes. Furthermore, the results of this study provide a basis for correlation with Tsumori and Yuhigaoka boreholes in the area (Fig.6). The results of tephra correlation determined the Ma number of each marine clay. The displacement rate is more lager western fault (0.18-0.26 $\mathrm{m} / \mathrm{ka}$ ) rather than main Uemachi fault $(0.11-0.14 \mathrm{~m} / \mathrm{ka})$ (Kitada et al., 2012).

Fig. 7 shows the flexure zone along the Uemachi fault. These flexure zones might be raise the amplification effect of seismic wave at the earthquake occurred. Therefore, we have to observe the behavior of seismic characteristics carefully.

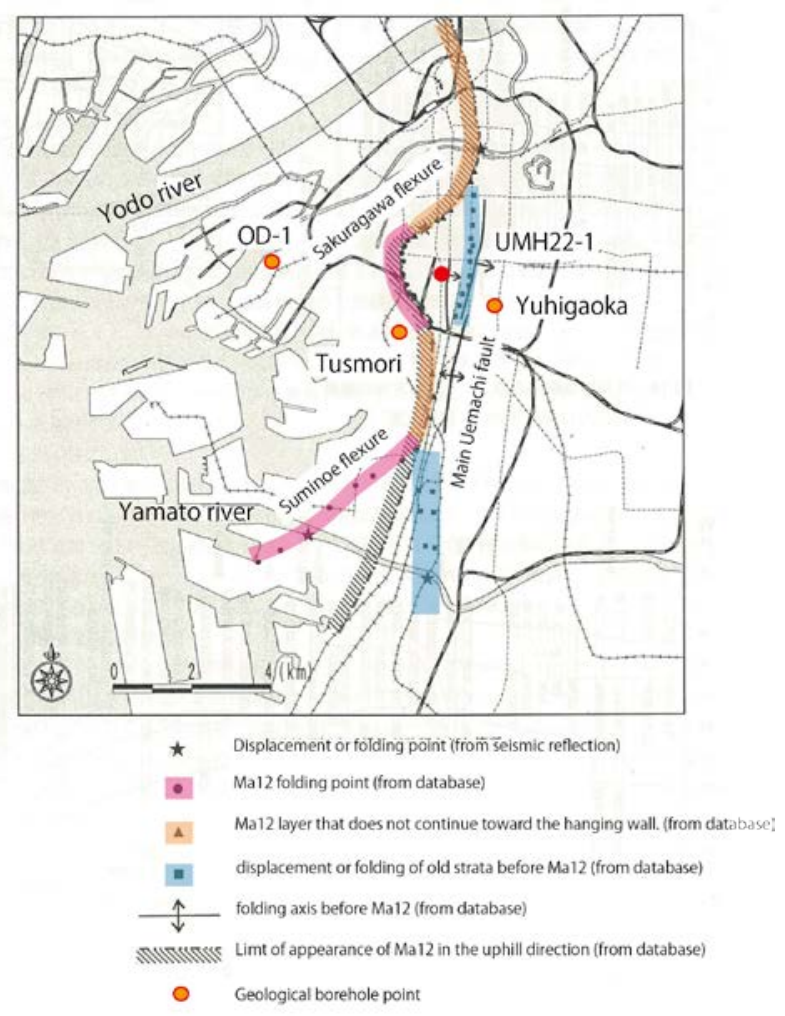

Fig. 6. Distribution of Uemachi fault trace in the Osaka lowland. Red line is type (a), yellow line is (b) and blue line is (c). The red and orange dots are geological borehole point estimated of displacement of fault. 


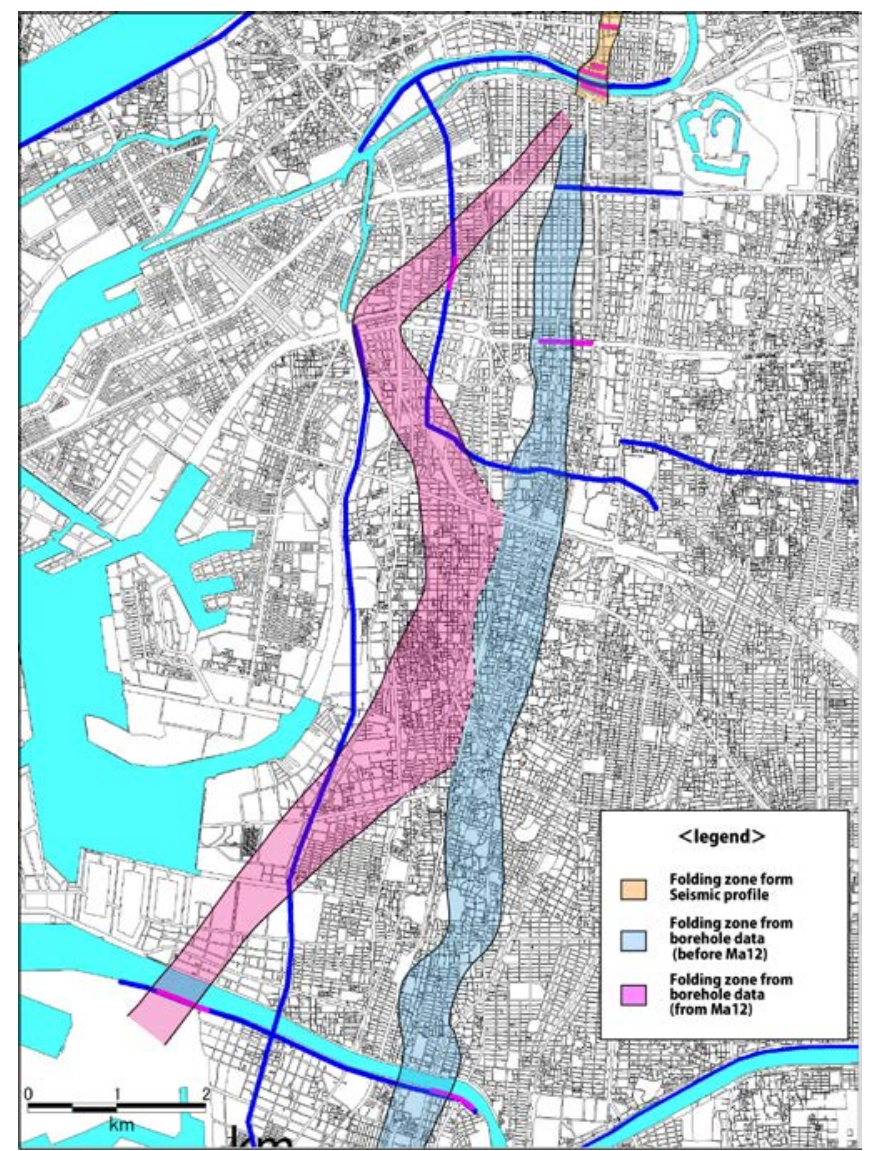

Fig. 7. Distribution of flexure zone along Uemachi fault trace.

\section{CONCLUSION}

The result of this study is summarized hereunder. The displacement rate of the flexure zone is $0.26 \mathrm{~m} / \mathrm{ka}$ and distributed parallel to the main fault. About 12 $\mathrm{km}$ length of Sakuragawa and Suminoe flexure are continuing and seems to be the one of the main fault in the Uemachi fault system.

In response to the results of this study, the source fault model for estimation of strong ground motion for Uemachi fault has be changed. Fig.8 shows two fault models. (a) is old fault model (Osaka prefecture, 2008) and (b) is new fault model (Sekiguchi et al., 2013). In the central part of Osaka plain, due to the surface fault trace changed toward west, high PGV and intensity area will be covered the main urban area. We have to provide more detail information of fault and subsurface geological model in order to prevention of disaster of fault activity.

\section{ACKNOWLEDGEMENTS}

Acknowledgments: This research was funded by MEXT as part of the integrated research project for the Uemachi active fault system in FY2011.

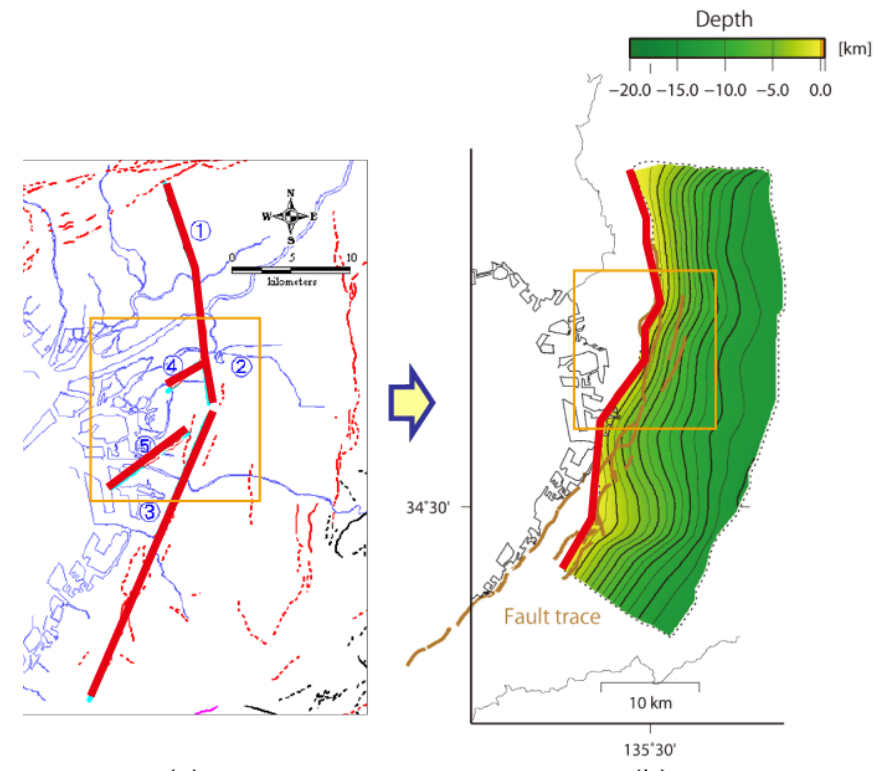

(b)

Fig. 8. Uemachi fault model for strong grand motion. Red lines show the surface fault line for Uemachi fault. (a) is the old fault model showing that the N-S fault is main fault (Osaka prefecture, 2008). (b) is the new fault model showing that Sakuragawa and Suminoe are the main fault (Sekiguchi et al., 2013).

\section{REFERENCES}

1) Geospatial Information Authority of Japan, "1:25,000 Active fault map in urban area,” (1996): Geological survey report D.1, No. 524,333,502.

2) Geo-database Information Committee of Kansai (2007): "Shin Kansai Jiban (Ground of Kansai Area - Osaka Plain to Osaka Bay-), 296p.

3) Kitada, N., Inoue, N., Takemura, K., Fukuda K., and Emura, T., (2011): Subsurface structure model around Kansai Airport according to re-interpretation of borehole data based on result of KIX18-1 core. Advances in Ground Technology and Geo-Information. Kok-Kwang Phoon, Siang Huat Goh \& Rui Fu Shen (ed.), 137-142.

4) Kitada, N., Takemura, K., Inoue, N., Mitamura M., Echigo, T., and Ito Y., (2012): Stratigraphy about UHM22-1 core and activity of Uemachi Fault. JPGU2012, SSS35-P17.

5) Osaka city (1996): Report of active fault resarchment of Uemachi fault.

http://www.hp1039.jishin.go.jp/danso/OsakaCtyfrm.htm (in Japanease).

6) Osaka prefecture (2008): Estimate of damage prediction of Uemachi fault and other active faults around Osaka prefecture.

http://www.pref.osaka.lg.jp/attach/3667/00000000/02.pdf, (in Japanease)

7) Sekiguchi, H., Asano, K., Yoshimi, M., Horikawa,.H., Saomoto, H., Hayashida, T., and Iwata T., (2013): Dynamic fault model of Uemachi fault and strong grand motion analysis. Report of the integrated research project for the Uemachi active fault system in FY2011, 38. (in Japanease) 